\title{
Sediment origin and budget in Sepetiba Bay (Brazil) - an approach based on multielemental analysis
}

\author{
C. Barcellos · L. D. de Lacerda · S. Ceradini
}

\begin{abstract}
Sediment origin and transport were determined in a shallow $447 \mathrm{~km}^{2}$ coastal lagoon in Brazil, using the distribution of major elements in bottom and suspended sediments. Applying multivariate analysis, the sum of normalized concentrations of $\mathrm{Ti}, \mathrm{Fe}$, and $\mathrm{Al}$ in sediments was selected to trace the terrigenous influence in bottom sediments, whereas $\mathrm{Ca}, \mathrm{Si}$, and $\mathrm{K}$ were used as indicators of marine influence. Sepetiba Bay bottom sediments are dominated by up to $80 \%$ terrigenous inputs. The open bay sediments are enriched in $\mathrm{P}$, $\mathrm{Mg}$, $\mathrm{K}$, and $\mathrm{Ca}$ because of the intensive water column primary production. The inner bay forms an independent circulation cell with a predominance of terrigenous sediments. The results suggest a long residence time for particles in the bay, demonstrated by the magnitude of resuspension flux compared to the total sediment input to the bay.
\end{abstract}

Key words Estuaries - Sedimentation . Resuspension $\cdot$ Sediment traps

\section{Introduction}

Sediments are a medium of transport, accumulation and storage of pollutants, indicators of environmental quality, and an agent of biota damage. In estuaries where sediments from different sources are mixed, knowing the origin of sediments is especially helpful in identifying the

Received: 29 May 1996 - Accepted: 17 December 1996

C. Barcellos $(\triangle)^{1} \cdot$ L. D. de Lacerda

Departamento de Geoquímica, Universidade Federal

Fluminense, Niterói, RJ 24020-007, Brazil

S. Ceradini

Divisione Ambiente, CISE, Via Reggio Emilia 39,

Segrate, Milan, I-20090, Italy

Present address:

${ }^{1}$ Departamento de Informações para a Saúde, Fundação Oswaldo Cruz, Avenida Brasil 4365,

Rio de Janeiro, RJ 21045-900, Brazil fate of pollutants and nutrients and tracing the possible cycles of particulate matter in the estuarine environment. Sepetiba Bay is a semienclosed lagoon $\left(447 \mathrm{~km}^{2}\right)$ located $60 \mathrm{~km}$ West of Rio de Janeiro, Brazil. There are $1.2 \mathrm{mil}-$ lion inhabitants and an important industrial park with over 400 industrial outlets in its drainage basin $\left(2065 \mathrm{~km}^{2}\right)$. Water depth ranges from $2 \mathrm{~m}$ in the inner zone to $20 \mathrm{~m}$ near the ocean entrance. A clockwise circulation pattern promotes the permanent exchange of water with the sea (Signorini 1980). Water quality studies, using salinity, suspended matter and nutrient concentrations, have shown the absence of vertical stratification, but demonstrated the influence of strong horizontal gradients (Azevedo and others 1996). The main sources of water, sediments and organic matter are the tidal input of marine water, an average fluvial water input of $200 \mathrm{~m}^{3} \mathrm{~s}^{-1}$, the intensive water column primary production, and an extensive mangrove vegetation, which covers $35 \%$ of the bay's perimeter (Barcellos and Lacerda 1993).

Sepetiba Bay is severely contaminated with heavy metals, in particular $\mathrm{Zn}$ and $\mathrm{Cd}$, due to large chemical and metallurgical plants located in the basin (Barcellos and Lacerda 1994). The dispersion and distribution patterns of these metals are controlled by sediment fluxes (Barcellos 1995). The study of sediment origin and dynamics in the bay is a fundamental step in understanding metal pollution in the area.

Large differences can be observed between the deposition and the final burial of sediments in shallow estuaries (Sanford 1992). In this work, the deposition of sediments was measured by means of sediment traps and the sedimentation (burial) was assessed from a review of existent data obtained in the bay by several methodologies, including dated sediment cores. The aim of this study was to identify the sediment sources of settling (trapped sediments) and deposited (bottom sediments) particulate matter in the bay by using elemental composition data and exploratory multivariate statistical analysis.

\section{Materials and methods}

The general location of Sepetiba Bay is shown in Fig. 1a. Sediment sampling sites and the location of sediment traps in Sepetiba Bay are shown in Fig. 1b. The sampling sites were distributed along the northern shore of the 


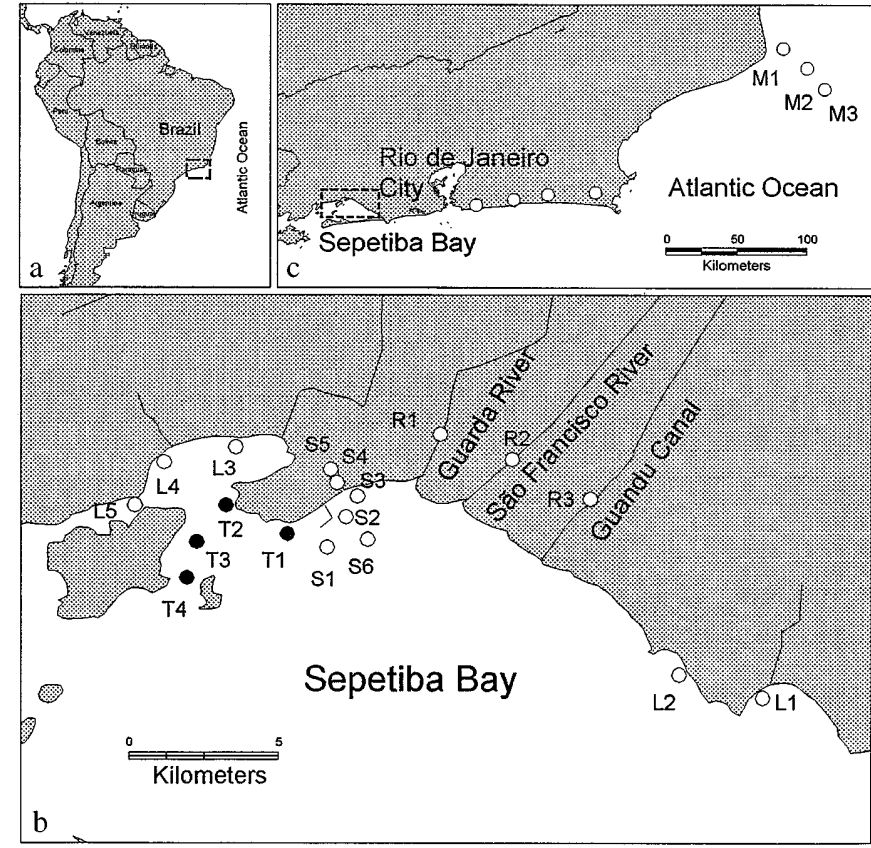

Fig. 1

Location maps of $\mathbf{a}$ the Rio de Janeiro coast, $\mathbf{b}$ Sepetiba Bay with the sampling sites and $\mathrm{c}$ marine sediment sampling sites

bay, where intensive sedimentation has occured during the last decades (Nogueira 1982). Other bottom sediment samples were collected along the coast of Rio de Janeiro and considered as representative of typical marine sediments of this part of Brazilian coast (Fig. 1c). Sediment traps are used to evaluate the primary production and long range transport of sediments in the ocean. In shallow waters, the contribution of resuspension must be evaluated due to the predominance of bed sediments in the total trapped material (Håkanson and others 1984). The sediment traps ( $85 \mathrm{~mm}$ diameter and $420 \mathrm{~mm}$ height) were deployed at four stations in the bay's transition zone between marine and riverine influences (T1, T2, T3, and T4) for 4 days during the austral summers of 1993 and 1994. Particulate matter in the traps was separated by centrifugation at $3000 \mathrm{rpm}$ for $10 \mathrm{~min}$.

Bottom sediment samples were collected from the upper $5 \mathrm{~cm}$ of mud deposits along the bay shore (L1, L2, L3, L4, and L5) and from deep (more than $3 \mathrm{~m}$ ) sites (S1, S2, S3, S4, S5, and S6) in the mixing zone of river and marine waters along the northwest coast of the bay. Fluvial bottom sediments (R1, R2, and R3) were collected in the major tributary rivers of the bay. Marine sediment samples (M1, M2, M3) were obtained from the continental shelf (water depth greater than $100 \mathrm{~m}$ ) off the Rio de Janeiro coast. All sediment samples were immediately wet sieved $(63 \mu \mathrm{m})$ and dried at $50{ }^{\circ} \mathrm{C}$ for $48 \mathrm{~h}$.

Macro element concentrations in the sediments were obtained by X-ray fluorescence technique using lithium tetraborate fusion and secondary regional certified samples as reference standards. At least 2 replicates were used for the standards, analytical blanks and samples, presenting reproducibility errors of $2-5 \%$. Phosphorus was determined by the ammonium molybdate colorimetric method. Dilution and standard addition test were performed in order to evaluate potential matrix interferences. Organic matter was estimated by gravimetry after heating the samples at $500{ }^{\circ} \mathrm{C}$ for $12 \mathrm{~h}$.

\section{Sediment composition and origin}

Origin and transport of the sediments were investigated by using concentration data of the major components as natural mineralogical tracers (Salomons and Mook 1987). Concentration values in the marine (M1, M2, and M3), riverine (R1, R2, and $\mathrm{R} 3$ ), shore (L1, L2, L3, L4, and L5), bay bottom sediment (S1, S2, S3, S4, S5, and S6) and trapped (T1, T2, T3, and T4) materials are presented in Table 1.

The range of major element concentrations indicates a dominance of the clay aluminum-silicate matrix. Variations in the major element concentrations suggest the existence of diverse sources of particulate matter and their mixture in the coastal region of the bay. Marine sediments contained lower $\mathrm{Al}$ and Fe concentrations than bay samples. Higher $\mathrm{Al}$ and $\mathrm{K}$ and considerably lower $\mathrm{Ca}$ concentrations were observed in respect to other estuarine sediments such as in the Rhine and Meuse Estuary sediments, which are under the influence of North Sea sediment deposition and dredging (Nolting and others 1990).

Correlation analysis, performed by using major elements data, showed significant positive relationships among $\mathrm{Ca}$, $\mathrm{K}$, and $\mathrm{Si}$, and between $\mathrm{Al}$ and $\mathrm{Ti}$. Iron exhibited a negative correlation with the first group of elements. These groups of elements have the main weight in two vectors of factor analysis and explain $73 \%$ of the sediment composition variance. Table 2 presents the obtained varimax rotate factors for major elements. These two groups of elements have also been used with success to trace terrestrial and marine sediments along other sectors of the southeast Brazilian coast (Carvalho and others 1993). The first factor (1) has a predominance of biogenic and marine origin elements ( $\mathrm{Ca}, \mathrm{K}$ and $\mathrm{Si}$ ) and the negative influence of Fe. The second factor (2), which is controlled by $\mathrm{Al}$ and $\mathrm{Ti}$ concentrations, was identified as a tracer of terrigenous sediments from riverine influence. The third factor (3), due to the weight of $\mathrm{P}$ and $\mathrm{Mn}$, is probably affected by the reworking of sediments and environmental redox condition changes at the sediment-water interface. The first two factors, which explain $60 \%$ of sediment composition variance, are possibly related to the origin of sediments, while only 13\% (from the third factor) of sediment quality variance is due to post-depositional processes. Higher $\mathrm{Mn}, \mathrm{Mg}$ and $\mathrm{P}$ concentrations (factor 3) are observed in the inner bay sediments (L1 and L2) when compared to riverine and marine endmembers.

Factor analysis was used in this work as an exploratory tool in order to define tracers of marine, continental, and 
Table 1

Major element and organic matter $(O M)$ concentrations in the sediments from Sepetiba Bay, Rio de Janeiro (values in \% with the exception of $\mathrm{Mn}$ and $\mathrm{P}$ in $\mu \mathrm{g} \mathrm{g}^{-1}$, dry weight; $n d$ not detectable)

\begin{tabular}{|c|c|c|c|c|c|c|c|c|c|c|}
\hline Sample & $\mathrm{Fe}$ & $\mathrm{Mn}$ & $\mathrm{Ti}$ & $\mathrm{Ca}$ & $\mathrm{K}$ & $\mathrm{Si}$ & $\mathrm{Al}$ & $\mathrm{Mg}$ & $\mathrm{P}$ & $\mathrm{OM}$ \\
\hline $\mathrm{R} 1$ & 4.9 & 790 & 0.60 & 0.30 & 1.07 & 19.0 & 8.0 & 0.79 & nd & 13.2 \\
\hline $\mathrm{R} 2$ & 5.4 & 910 & 0.62 & 0.31 & 1.11 & 15.2 & 8.4 & 0.82 & 310 & 16.6 \\
\hline R3 & 4.3 & 700 & 0.82 & 0.34 & 1.67 & 18.4 & 6.4 & 0.61 & 240 & 8.9 \\
\hline L1 & 4.4 & 2330 & 0.66 & 0.50 & 1.38 & 18.5 & 6.5 & 1.66 & 400 & 14.3 \\
\hline $\mathrm{L} 2$ & 4.7 & 3310 & 0.63 & 0.39 & 1.38 & 17.6 & 7.4 & 1.23 & 620 & 14.2 \\
\hline L3 & 3.7 & 460 & 0.68 & 0.50 & 1.67 & 17.1 & 6.7 & 1.33 & 460 & 15.8 \\
\hline L5 & 3.1 & 310 & 0.57 & 0.44 & 1.66 & 18.0 & 5.2 & 0.79 & 190 & 15.7 \\
\hline S1 & 5.2 & 520 & 0.76 & 0.30 & 1.30 & 19.1 & 8.4 & 0.84 & nd & 12.7 \\
\hline S2 & 4.5 & 380 & 0.77 & 0.28 & 1.31 & 18.6 & 7.8 & 0.82 & nd & 13.0 \\
\hline S3 & 3.9 & 320 & 0.61 & 0.31 & 1.51 & 20.9 & 6.1 & 1.32 & nd & 10.1 \\
\hline S4 & 7.3 & 320 & 0.56 & 0.32 & 1.16 & 16.3 & 5.6 & 1.29 & 340 & 12.3 \\
\hline S5 & 6.3 & 280 & 0.67 & 0.30 & 1.33 & 16.9 & 6.9 & 1.16 & 100 & 12.7 \\
\hline S6 & 4.5 & 450 & 0.75 & 0.35 & 1.34 & 18.4 & 7.8 & 0.81 & 210 & 14.5 \\
\hline T3 & 3.5 & 440 & 0.56 & 0.52 & 2.17 & 21.4 & 6.1 & 0.98 & 740 & 11.6 \\
\hline $\mathrm{T} 4$ & 4.8 & 590 & 0.62 & 0.57 & 1.64 & 20.0 & 6.4 & 0.92 & 450 & 17.2 \\
\hline M1 & 1.6 & 390 & 0.37 & 0.44 & 1.54 & 31.3 & 3.0 & 0.30 & 160 & 2.9 \\
\hline M2 & 1.5 & 350 & 0.43 & 0.35 & 1.13 & 32.9 & 2.4 & 0.23 & 230 & 2.4 \\
\hline M3 & 1.8 & 400 & 0.78 & 0.42 & 0.91 & 32.7 & 1.9 & 0.29 & 120 & 2.7 \\
\hline
\end{tabular}

Table 2

Factor components for major elements of Sepetiba Bay sediments after varimax rotation

\begin{tabular}{|c|c|c|c|}
\hline Factor & 1 & 2 & 3 \\
\hline $\mathrm{Fe}$ & -0.88 & -0.02 & 0.06 \\
\hline $\mathrm{Mn}$ & 0.03 & -0.01 & 0.84 \\
\hline $\mathrm{Ti}$ & 0.02 & 0.82 & -0.08 \\
\hline $\mathrm{Ca}$ & 0.70 & -0.54 & 0.18 \\
\hline K & 0.85 & -0.24 & -0.21 \\
\hline $\mathrm{P}$ & -0.28 & -0.11 & 0.74 \\
\hline $\mathrm{Si}$ & 0.79 & 0.00 & -0.10 \\
\hline $\mathrm{Al}$ & -0.29 & 0.79 & 0.38 \\
\hline $\mathrm{Mg}$ & 0.07 & -0.67 & 0.40 \\
\hline
\end{tabular}

authigenic sediments. A normalization of factors was obtained by summing the concentration of two groups of the three major elements $(\mathrm{Ca}, \mathrm{Si}$, and $\mathrm{K}$ as factor $1 ; \mathrm{Ti}$, $\mathrm{Fe}$, and $\mathrm{Al}$ as factor 2) divided by their respective mean. Figure 2 shows the plots of factors 1 and 2 for the sediments of Sepetiba Bay. A hypothetical dilution curve linking the marine ( $\mathrm{M}$ samples) and riverine ( $\mathrm{R}$ samples) endmembers is drawn. The majority of sediment samples lie above the expected dilution curve. This enrichment is due to the incorporation of $\mathrm{K}$ and $\mathrm{Ca}$ into the particulate matter and can be considered as biogenic. Higher enrichments are observed for trapped materials (squares in Fig. 2). The compositional similarity between trapped sediment samples and bottom sediments, as well as their proximity to the western shore (as shown in Fig. 1b) may indicate the predominance of resuspended sediments in

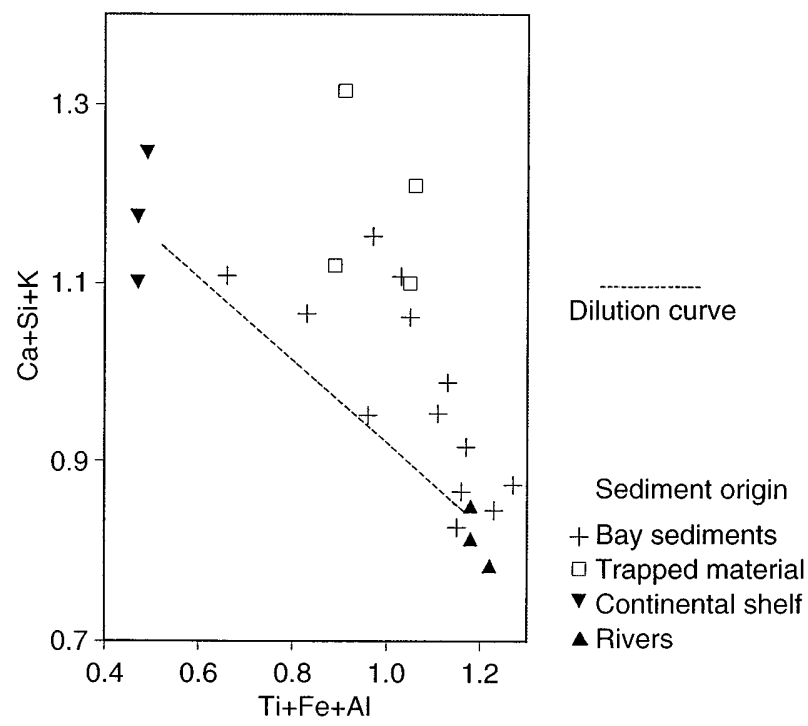

Fig. 2

Relation between continental and marine indicators.

Normalized element concentrations were summed for each sample. Squares represent the sediment trap samples

this area and the minor importance of primary production on sediment composition.

The biogenic enrichment of each element in the bay sediment samples were calculated from the difference between the observed concentrations and those predicted from the dilution curve, linking the marine and continental endmembers. The Sepetiba Bay bottom sediments are enriched in P (5-fold), Mg (1.5-fold), K (1.4-fold), and Ca 
(1.3-fold). Other elements, such as Si, Fe, Mn, Ti, and Al are well fitted to the expected dilution curve and have little or no enrichment due to primary production. From the vertical deposition profile of elements in ocean traps, $\mathrm{Al}$ and $\mathrm{K}$ were characterized as refractory; $\mathrm{Si}, \mathrm{Ca}$, and $\mathrm{Mg}$ as biogenic; and $\mathrm{Fe}$ and $\mathrm{Mn}$ as scavenged elements (Brewer and others 1980). The behavior of Si in the bay is in agreement with the observed conservative trend verified in other estuaries as reviewed in Boyle and others (1974). In this case, the presence of Si acts predominantly as a diluter of terrigenous elements, despite the fact that it has an importance to some living organisms (for example diatoms).

The sum of the relative elemental increase due to the biogenic component represents $4.4 \%$ of the bulk sediment mass in Sepetiba Bay. Other elements such as C, S, and $\mathrm{N}$, which have large participation in the total mass of biological materials, were not analyzed because of methodological restrictions. Organic carbon has a mean ratio to P from 30:1 to 40:1 in organic-rich sediments (Sundby and others 1992). Other works showed that Sepetiba Bay bottom sediments contain around 10\% organic carbon (Rezende 1993).

The distribution ratios between marine and continental, as well as between biogenic and lithogenic materials in Sepetiba Bay sediments (shown in Table 3) were calculated based on the distance between the observed element concentrations and those expected from the dilution curve of endmembers.

Continental origin of sediments is largely predominant in the inner Sepetiba Bay, where river sediments are deposited due to shore parallel currents. The transport of riverine sediments along the eastern shore was observed by means of remote sensing (Argento and Vieira 1989). The existence of an almost independent hydrodynamic cell in the eastern part of the bay was pointed out by Bronniman and others (1981) which enlarges the water residence time and promotes the sedimentation of river-transported particles. The marine influence on bottom sediment composition is higher for the open western area. The predominance of marine-derived particles in bottom sediments has been pointed out in other well-studied estuaries such as the Savannah (Mulholland and Olsen 1992) and Elbe (Schoer 1990) Rivers. In the Rhine-Meuse Estuary, however, between 55 and $65 \%$ of the inorganic sediments are of terrigenous origin (Salomons and Mook 1987). The "inverse estuaries", which trap all the conti-

Table 3

Estimated mean fraction of continental, marine, biogenic and lithogenic of Sepetiba Bay sediments (in percentage of total mass)

\begin{tabular}{|c|c|c|c|c|}
\hline & $\begin{array}{l}\text { Conti- } \\
\text { nental }\end{array}$ & Marine & $\begin{array}{l}\text { Bio- } \\
\text { genic }\end{array}$ & $\begin{array}{l}\text { Litho- } \\
\text { genic }\end{array}$ \\
\hline Inner bay & 79 & 21 & 8 & 92 \\
\hline Open bay & 50 & 50 & 10 & 90 \\
\hline Trapped material & 64 & 36 & 20 & 80 \\
\hline
\end{tabular}

nental sediment input and a large fraction of marinetransported sediments, are commonly found in coastal embayments with small freshwater input (Biggs and Howell 1984). Sepetiba Bay is likely to be this sort of estuary and has a large sediment trapping efficiency. The participation of the estimated organic matter (biogenic) fraction (between 8 and $10 \%$ of bottom sediment, dry weight) is in agreement with the measured content of organic matter in the Sepetiba Bay bottom sediments (about 13\%, Table 1). Considerable quantities of accumulated organic matter can also be a result of the input of particulate organic matter by rivers. In the inner area, where river-transported sediments are predominant, biogenic elements represent less than $10 \%$ of sediment total weight. The persistence of continental originated organic matter in the Sepetiba Bay sediments was verified by using organic tracers (Rezende 1993).

The authigenic origin of a portion in the total deposited organic matter is reinforced by the observed enrichment of $\mathrm{P}, \mathrm{Mg}, \mathrm{K}$ and $\mathrm{Ca}$ in respect to marine and riverine sources of sediments. The suspended and benthic biota were pointed out as a main component in the "biologically mediated sedimentation" due to its filtering capacity which sometimes exceeds the water input of the estuaries (Biggs and Howell 1984).

\section{Sedimentation, resuspension and deposition}

Sediment deposition rates, measured by means of sediment traps, varied from 5 (in the westernmost open bay site) to $50 \mathrm{mg} \mathrm{cm}^{-2} \mathrm{day}^{-1}$ (at the northern shore). Figure 3 shows the deposition rates related to the height above the bay's bottom. The higher sediment deposition rates were measured in an embayment with noncompacted sediment bed, exposed to wave action and with

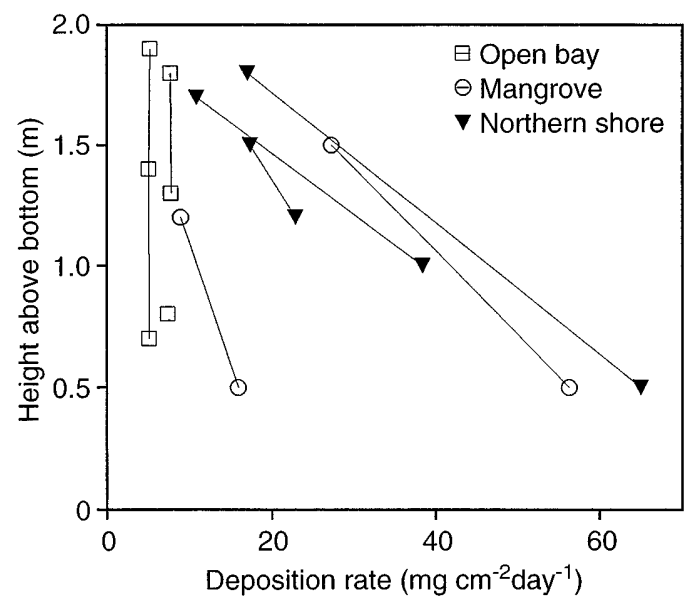

Fig. 3

Deposition rates at different heights in Sepetiba Bay as measured by sediment traps 
Table 4

Sedimentation and deposition rates in Sepetiba Bay compared to other coastal regions

\begin{tabular}{|c|c|c|c|}
\hline & \multicolumn{2}{|c|}{ Sedimentation rate } & \multirow{2}{*}{$\begin{array}{l}\text { Deposition rate } \\
\left(\mathrm{mg} \mathrm{cm}^{-2} \text { day }^{-1}\right)\end{array}$} \\
\hline & $\left(\mathrm{cm}\right.$ year $\left.{ }^{-1}\right)$ & $\left(\mathrm{mg} \mathrm{cm}^{-2}\right.$ day $\left.^{-1}\right)$ & \\
\hline \multicolumn{4}{|l|}{ Sepetiba Bay } \\
\hline Open bay & $0^{\mathrm{a}}$ & 0 & $2700^{\mathrm{b}}$ \\
\hline Northern Shore & $1.2^{\mathrm{c}}$ & $720^{\mathrm{d}}$ & $7500^{b}$ \\
\hline Mangrove & $0.8-1.0^{\mathrm{e}}$ & $400-600^{\mathrm{d}}$ & $4400^{\mathrm{b}}$ \\
\hline River delta & $3-5^{a}$ & $3300^{\mathrm{d}}$ & - \\
\hline Engenho bay & $1.3^{\mathrm{f}}$ & $650^{\mathrm{f}}$ & - \\
\hline Inner area & $0.5^{\mathrm{a}}$ & $300^{\mathrm{d}}$ & - \\
\hline \multicolumn{4}{|l|}{ Other regions } \\
\hline Guanabara Bay & $0.9^{\mathrm{g}}$ & - & - \\
\hline Hong Kong Bay & $0.3-0.6^{\mathrm{h}}$ & - & - \\
\hline Rio de Janeiro coast & - & - & $36-475^{i}$ \\
\hline Japan Sea & - & $1.7^{\mathrm{j}}$ & 5.1 \\
\hline \multicolumn{2}{|l|}{ Remarks and references } & \multicolumn{2}{|c|}{${ }^{\mathrm{f}}$ Heavy metal record (Barcellos and others 1991) } \\
\hline \multicolumn{2}{|c|}{ a Bathimetric map comparison (Leitão Filho 1995) } & \multicolumn{2}{|c|}{${ }^{\mathrm{g}}$ Bathimetric map comparison (Amador 1988) } \\
\hline \multirow{2}{*}{\multicolumn{2}{|c|}{ b Based on sediment trap measurements, this study }} & \multicolumn{2}{|c|}{${ }^{\mathrm{h}}$ Lo and Fung (1992) } \\
\hline & ${ }^{\mathrm{c}}$ Pesticide record (Japenga and others 1988) & \multicolumn{2}{|c|}{${ }^{\mathrm{i}}$ Knoppers and Pollehne (1991) } \\
\hline \multirow{2}{*}{\multicolumn{2}{|c|}{ A Assuming a bulk sediment density of $0.5 \mathrm{~g} \mathrm{~cm}^{-3}$}} & \multicolumn{2}{|c|}{ j Masuzawa and others (1989) } \\
\hline & & & \\
\hline
\end{tabular}

high sedimentation rates. The presence of vertical gradients of deposition rates in shore traps demonstrates a local resuspension of sediments, where bottom sediments are fine grained. Conversely, where bottom sediments are sandy (open bay samples), the deposition rates are almost constant throughout the water column. A baseline level of deposition rate is observed between 5 and $8 \mathrm{mg}$ $\mathrm{cm}^{-2} \mathrm{~d}^{-1}$, which can be due both to the long-range transport of particles and the primary production in the bay water. Table 4 presents the reported sedimentation and deposition rates in selected areas of Sepetiba Bay. These values are compared to other coastal regions.

Sedimentation rates in the bay were estimated by previous works leading to a range of $0.8-1.3 \mathrm{~cm}_{\text {year }}{ }^{-1}$. These values are high when compared to other coastal environments. The highest sedimentation rates were found in the major river estuaries along the northern shore of the bay, where shoreline transgression has been observed. On the other hand, erosion and shoreline transgression have been verified in the southern regions of the bay (Nogueira 1982).

Based on the observed sedimentation rate range, an average particle burial flux of $400-700 \mathrm{mg} \mathrm{cm}^{-2}$ year $^{-1}$ is calculated assuming $0.4-0.6 \mathrm{~g} \mathrm{~cm}^{-3}$ for the bulk sediment density for noncompacted clay sediments (Håkanson and others 1984; Barcellos and others 1991). The order of magnitude difference between sediment deposition and burial rates is probably due to frequent resuspension episodes and the intensive sediment production in the water column. This means that particles settle and are resuspended about 10 times before their final burial. This cycling characterizes Sepetiba Bay as a highly active estuary (Sanford 1992).
River sediment inputs were measured by Watts (1990) and Rezende (1993) as $0.30-0.59 \times 10^{6}$ tons year $^{-1}$, respectively. These figures are underestimated according to Argento and Vieira (1989) because they reflect only dry weather periods. Assuming a quadratic relation between solid and dissolved river flows, sediment input increases 4 times for a doubling of river flow rate (Linsley and others 1975). During the wet season (summer), sediment transport can reach up to $1.8 \times 10^{6}$ tons year $^{-1}$.

A sediment mass balance was estimated based on the measured riverine input and mixing rates between continental/marine and biogenic/lithogenic sources as discussed above. Internal fluxes, such as resuspension and deposition, were measured by means of sediment traps. Figure 4 shows the estimated sediment fluxes in Sepetiba Bay.

The calculated total input of particulate matter is in good agreement with the verified mean sedimentation consid-

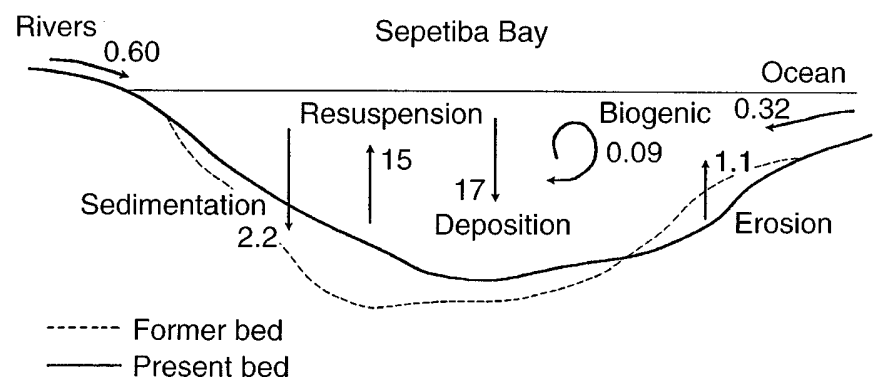

Fig. 4

Estimated mass sediment fluxes in Sepetiba Bay (in $10^{6}$ tons year $^{-1}$ ) 
ering the bathimetric map evolution (Leitão Filho 1995). Differences between sedimentation and erosion, as well as between resuspension and deposition are due to the external sediment inputs to the bay, leading to a convergent value about $1 \times 10^{6}$ tons year ${ }^{-1}$. Resuspension and deposition fluxes of sediments ( 15 and $17 \times 10^{6}$ tons year $^{-1}$, respectively) overcome the sum of sediment inputs by one order of magnitude (around $1 \times 10^{6}$ tons year ${ }^{-1}$ ) which indicates the long residence time of sediments in the bay waters.

The mean settling velocity for open bay particles was estimated between 1 and $4 \mathrm{~m} \mathrm{day}^{-1}$ (Barcellos 1995). Considering the bay dimensions and the advectional currents, particles can travel widely before deposition and sinking. Resuspension episodes thus have an important role in the internal redistribution of sediments. On the other hand, resuspension can be responsible for the release of particles linked to heavy metals, which is a great concern in this bay (Barcellos and Lacerda 1993).

\section{Conclusions}

Sedimentation in the Sepetiba Bay is controlled by the mixture of riverine, marine and autochthonous sediments. River-transported sediments are predominant in the bay and are deposited mainly in the eastern region of the bay. Marine sediment contribution is only observed in the western shore deposits. A small fraction of shore sedimentation is a consequence of the intensive local primary production, which is indicated by the enrichment of $\mathrm{P}, \mathrm{Mg}, \mathrm{K}$ and $\mathrm{Ca}$ in bottom and suspended sediments. The high sedimentation rates (around $1 \mathrm{~cm}$ year ${ }^{-1}$ ), reported for some areas in the bay, are explained by riverine input. Vertical internal fluxes, represented by resuspension and deposition of sediments, overcome (by a factor of 15) the external inputs promoting a remobilization of fine particles in the bay and are responsible for an enrichment of $\mathrm{K}$ and $\mathrm{Mn}$ in suspended particles. The frequent resuspension episodes and the long-range transport of heavy metal-rich suspended matter promote metal remobilization and dispersion in the bay. The long residence time of contaminated particles in the bay should concern the monitoring of long-term effects of heavy metal pollution.

Acknowledgements Coastal sediment samples were kindly provided by C.E.V. Carvalho. All analyses were performed in the CISE laboratories during 1993. Particular thanks are given to A. Zoboli for his attention during XRF analysis. This work was undertaken with the support of the ICTP Programme for Training and Research in Italian Laboratories (Trieste, Italy) and the Conselho Nacional de Desenvolvimento Científico e Tecnológico (CNPq-Brazil).

\section{References}

Amador ES (1988) Assoreamento da Baía de Guanabara - taxas de sedimentação. An Acad Bras de Ciênc 52:723-742

Argento MAF, Vieira AC (1989) Impacto ambiental na Praia de Sepetiba. Proceedings of the 3rd Congresso Brasileiro de Defesa do Meio Ambiente, Rio de Janeiro, pp 187-201

Azevedo F, Patchineelam SR, Knoppers B (1996) Massas de água e material em suspensão na Baía de Sepetiba. Sci Cult (submitted)

BArCellos C (1995) Geodinâmica de cádmio e zinco na Baía de Sepetiba. Doctoral Thesis, Instituto de Química. Universidade Federal Fluminense, Niterói, Brazil

Barcellos C, LACERda LD (1993) Cadmium behaviour in a tropical estuary In: CEP Consultants, Heavy metals in the environment, Toronto, $1: 169-172$

Barcellos C, LACERdA LD (1994) Cadmium and zinc source assessment in the Sepetiba Bay and basin region. Environ Monit Assess 29:183-199

Barcellos C, Rezende CE, Pfeiffer WC (1991) Zinc and cadmium production and pollution in a Brazilian coastal region. Mar Pollut Bull 22:558-561

Biggs RB, Howell BA (1984) The estuary as a sediment trap: alternative approaches to estimating its filtering efficiency. In: Kennedy VS (ed), The estuary as a filter. Academic Press, New York, pp 107-129

Boyle ER, Collier F, Dengler AT, Edmond JM, Ng AC, STALLARD RF (1974) On the chemical mass-balance in estuaries. Geochim Cosmochim Acta 38:1719-1728

Brewer PG, Nozaki Y, Spencer DW, Fleer AD (1980) Sediment trap experiments in the deep North Atlantic: isotopic and elemental fluxes. J Mar Res 38:703-728

Bronniman P, Dias-Brito D, Moura JA (1981) Foraminíferos da fácies mangua da planície de maré de Guaratiba, Rio de Janeiro, Brasil. In: Congresso Latinoamericano de Paleontologia (proceedings vol 2); Porto Alegre, Brazil, pp 877-891

Carvalho CE, Lacerda LD, Rezende CE, Abrão JJ (1993) Titanium and calcium as tracers for continental and oceanic materials in the Brazilian continental shelf. In: Proceedings of the 3rd Simpósio de Ecossistemas da Costa Brasileira, Rio de Janeiro, pp 122-127

HÅKanson L, Floderus S, Wallin M (1984) Sediment trap assemblages - a methodological description. Hydrobiologia 176/177:481-490

Japenga W, Wagenar WJ, Salomons W, Lacerda LD, PatCHINEELAM SR, LEITÃo-Filho CM (1988) Organic micropollutants in the Rio de Janeiro coastal region, Brazil. Sci Total Environ 75:249-259

Knoppers B, Pollehne F (1991) The transport of carbon, nitrogen and heavy metals to the offshore sediments by plankton sedimentation. In: Ekau W (ed) Brazilian German Victor Hensen Programme - Joint Oceanographic Projects. Cruise Report, Bremerhaven. pp 25-30

LEITÃo-FılHo CM (1995) Distribuição de metais pesados nos sedimentos superficiais da Baía de Sepetiba. Masters Thesis, Instituto de Química, Universidade Federal Fluminense, Niterói, Brazil

Linsley RK, Kohler MA, Paulhus JLH (1975) Hydrology for engineers, 2nd edn McGraw-Hill Kogakusha Press, Tokyo

Lo CK, Fung YS (1992) Heavy metal pollution profiles of dated sediment cores from Hebe Haven, Hong Kong. Water Res 26: 1605-1620

Masuzawa T, Noriki S, Kurosaki T, Tsunogai S, Koyama M (1989) Composition change of settling particles with water depth in the Japan Sea. Mar Chem 27:61-78 
Mulholland PJ, Olsen CR (1992) Marine origin of Savannah River estuary sediments: evidence from radioactive and stable isotope tracers. Estuarine Coastal Shelf Sci 34:95-107

Nogueira J JR (1982) Estudo sedimentológico da Baía de Sepetiba (RJ): síntese dos trabalhos existentes e sua aplicação para fins de geologia de engenharia. In: 32 Congresso Brasileiro de Geologia, Rio de Janeiro, vol 4, pp 1676-1688

Nolting RF, Sundby B, Duinker JC (1990) Behaviour of minor and major elements in the suspended matter in the Rhine and Meuse Rivers and Estuary. Sci Total Environ 97/ 98:169-183

Quevauviller P, Donard OFX, Wasserman JC, Martin FM, SCHNEIDER J (1992) Occurrence of methylated tin and dimethyl mercury compounds in a mangrove core from Sepetiba Bay, Brazil. Appl Organomet Chem 6:221-228

Rezende CE (1993) Origem, transporte e destino da matéria orgânica na interface fluvio-marinha, sob diferentes condições de uso do solo e sua relação com o trânsito de poluentes metálicos na Baía de Sepetiba - RJ. Doctoral thesis, Instituto de Biofísica, Universidade Federal do Rio de Janeiro, Rio de Janeiro
SAlomons W, Mook WG (1987) Natural tracers for sediment transport studies. Cont Shelf Res 7:1333-1343

SANFORD LP (1992) New sedimentation, resuspension, and burial. Limnol Oceanogr 37:1164-1178

Schoer JH (1990) Determination of the origin of suspended matter and sediments in the Elbe Estuary using natural tracers. Estuaries 13:161-172

Signorini SR (1980) A study of the circulation in Bay of Ilha Grande and Bay of Sepetiba: part 1, a survey of the calculation based on experimental field data. Bol Inst Oceanogr 29:41-55

Sundby B, Gobeil C, Silverberg N, Mucci A (1992) The phosphorus cycle in coastal marine sediments. Limnol Oceanogr 37:1129-1145

Watts PPG (1990) Aporte de metais pesados para a Baía de Sepetiba seu comportamento na região estuarina. Masters Thesis, Instituto de Química, Universidade Federal Fluminense, Niterói, Brazil 